\title{
Stock option taxation: a missing piece in European innovation policy?
}

\author{
Magnus Henrekson • Tino Sanandaji
}

Accepted: 30 November 2017 / Published online: 5 March 2018

C) The Author(s) 2018. This article is an open access publication stock options can be a strategy for European countries to catch up in entrepreneurial finance. This tax policy would narrowly target entrepreneurial startups without requiring broad tax cuts. The favorable tax treatment of stock options allows the state to promote firms that rely on entrepreneurial finance and make use of these types of contracts without lowering taxes for other sectors of the economy.

Keywords Entrepreneurship · Innovation · Institutions · Tax policy $\cdot$ Stock options $\cdot$ Venture capital

JEL classification $\mathrm{L} 26 \cdot \mathrm{H} 25 \cdot \mathrm{H} 3 \cdot \mathrm{K} 34$

\section{Introduction}

Financing firm creation and expansion is a first-order problem in entrepreneurial venturing. Investing in innovative entrepreneurship through startup firms requires dealing with high initial costs, long lags, uncertain and skewed returns, and the lack of collateral. Young, rapidly growing firms tend to face capital constraints while also lacking access to capital markets due to uncertainty and the high fixed costs of investing in smaller firms (e.g., Chittenden et al. 1996; Polzin et al. 2016). Entrepreneurs rely on a multitude of sources of finance, including own equity, funds from family and friends, bank debt, angel investors, and loans from public bodies. Different types of finance can be complementary, and most entrepreneurs rely on a mix of sources (Robb and Robinson 2014). 
Particularly in high-tech sectors, the emergence of venture capital (VC) funding represented a transformative change for the problem of funding new firms. Despite its advantages, only a fairly small number of countries have been able to develop a significant VC sector. These countries usually have a high GDP per capita, strong property and contractual rights, advanced financial sectors, and knowledge-intensive industries. Yet, not all economies that fulfill these prerequisites develop a vibrant VC sector. This suggests that the aforementioned factors may be necessary but not sufficient for the VC sector to flourish-and that other factors (such as tax regimes) play a role.

The VC sector in the USA remains significantly larger than that in Europe and East Asia. This is so despite the fact that Western Europe has welldeveloped financial markets and is not far behind the USA in terms of R\&D spending, the high-tech sector's share of the economy, and the education level of its workforce (e.g., Henrekson and Sanandaji 2015).

The VC sector has grown in Europe since the early 1990s; however, as shown in Fig. 1, it remains far smaller than that in the USA. This is particularly the case in Eastern Europe, where the size of the VC industry is a mere third of the level in Western Europe. The newly emerged market economies in Eastern Europe still lack the mature financial sectors and the strong property and contractual rights required for a large VC sector (Åslund and Djankov 2017; Elert et al. 2017). These binding institutional constraints appear to have prevented the emergence of VC activity in Eastern European countries, despite the fact that owner-level taxes in many cases are low. In contrast to Eastern Europe, VC activity has increased significantly in China, with a level currently on par with that of Western Europe as a share of GDP.

Admittedly, many entrepreneurs do not use VC funding, and entrepreneurship can be funded in other ways. From a policy perspective, we are ultimately interested in the link between option taxes and entrepreneurial activity, not just VC. Option-like contracts are used by entrepreneurs outside the VC sector, and VC is not the only means through which option taxes are likely to influence entrepreneurship. However, while VC activity can be readily measured and compared across countries and over time, it is notoriously difficult to systematically measure Schumpeterian entrepreneurship, i.e., innovative venture creation with the ambition to grow (Henrekson and Sanandaji 2017). Therefore, the size of the $\mathrm{VC}$ sector is also useful as an empirical proxy for the broader effect of taxes on Schumpeterian entrepreneurship.

The US VC sector is not only much larger than its European counterpart, but it also differs in its compensation structure. It relies almost universally on stock options to compensate founders, CEOs, and key employees, while stock options are far less common in other countries that tend to use a mix of financial instruments (Bascha and Walz 2001; Hege et al. 2003; Schwienbacher 2005; Cumming 2012).

The stock options frequently used in VC-backed ventures are call options on the common stock of a company, which are granted to employees as a part of their remuneration packages. The grantee obtains the options to acquire a prespecified share of equity under certain well-specified circumstances. If the business is less successful or if the founder prematurely leaves the firm, the option loses its value. Economic theory offers elegant explanations for the complicated reward structure in entrepreneurial finance. Stock options have proven to be a suitable compensation form in VC finance, because such options solve common contractual problems by efficiently allocating control between investors and entrepreneurs (Gompers 1997; Black and Gilson 1998; Kaplan and Strömberg 2003).

Why then are stock options not used to the same extent in VC-backed ventures in Europe? Could there be factors that discourage the use of stock options in compensation contracts which result in the smaller VC sectors compared to those in the USA? This paper argues that the tax treatment of employee stock options is a major factor explaining cross-country differences in the VC sector size.

The US tax system treats income from exercised employee stock options as capital gains, allowing earnings to be postponed and taxed at a lower rate. ${ }^{1}$ The favorable tax treatment of employee stock options

\footnotetext{
${ }^{1}$ This is the case for so-called incentive stock options (ISOs), which are the type discussed here. To benefit from the favorable capital gains tax, the employee must comply with certain additional tax code requirements. Most importantly, shares acquired upon the exercise of ISOs must be held for at least 1 year after the date of exercise and 2 years after the ISOs were granted. If other conditions are satisfied, including a 5-year holding period, the owner of stock in a small business is eligible for a further rate reduction. A holder of small business stock can also benefit from the "rollover" rule, under which tax that otherwise would be due from a sale of stock is deferred if the taxpayer reinvests sale proceeds in other qualifying stock (Gilson and Schizer 2003; Scholes et al. 2014).
} 
Fig. $1 \mathrm{VC}$ investment as a share of GDP in Western Europe, Eastern Europe, the USA, and China, 1989-2015. Western Europe $=$ the GDP-weighted average for Germany, France, Italy, Spain, the Netherlands, Greece, Belgium, Portugal, Sweden, Austria, Denmark, Finland, Ireland, Luxembourg, Switzerland, Norway, and Iceland. Eastern Europe $=$ the GDP-weighted average for Poland, Hungary, Romania, Bulgaria, Czech Republic, Slovakia, Slovenia, Estonia, Latvia, and Lithuania. Source: Eurostat for Eastern and Western Europe, National Venture Capital Association for the United States, and the Asian Venture Capital Journal for China

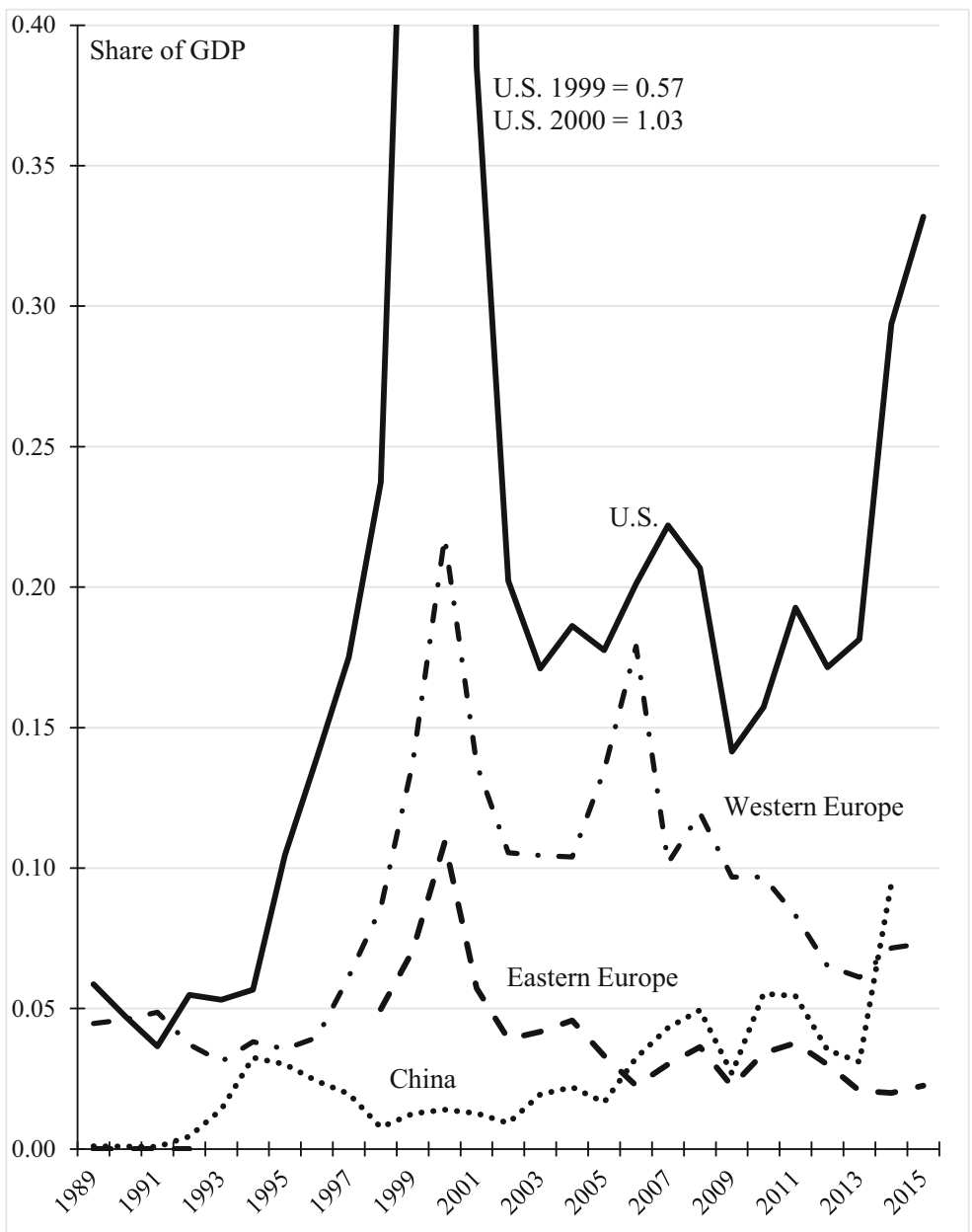

confers a sizable tax advantage to US entrepreneurs (Gilson and Schizer 2003; Cumming 2005a). No such advantage is enjoyed by individuals in most other sectors of the US economy, and, as we will show, the tax advantages are also not enjoyed by entrepreneurs in most other developed countries. Because stock options are advantageous in the $\mathrm{VC}$ sector, the favorable tax treatment has led to widespread use and a low effective taxation of VC-funded entrepreneurship as a whole. This helps explain the more common use of stock options and the high VC activity in the USA compared to that in other industrialized countries.

We study the relationship between taxes on employee stock options and VC activity in 22 countries, 13 of which are in Western Europe. Because the effective tax rate of stock option contracts depends on tax practice, effective rates are not immediately apparent from comparisons between statutory tax rates. Investors in each country tend to design their contractual agreements in ways that reduce the effective tax burden. Therefore, we estimate the effective tax rate based on a standardized case of a typical entrepreneurial startup using stock option contracts.

National tax rates vary widely, ranging from $72 \%$ in Italy to $7 \%$ in Ireland. There is a negative cross-country correlation between the effective tax rate on employee stock options and the rate of VC activity, both directly and when controlling for several alternative or complementary explanations. While this correlation does not prove a causal link, it does support the notion that low taxes on employee stock options promote VC-funded entrepreneurship.

Hence, more lenient taxation of gains from employee stock options may be a useful tool to achieve the policy goals of promoting entrepreneurship and the VC sector. Lowering these tax rates would narrowly target firms in 
the entrepreneurial sector that are able to attract VC, while broad tax cuts are associated with large revenue losses and increasing inequality. This allows the state to promote a small but strategic sector of the economy with negligible distortionary effects.

The remainder of the paper is structured as follows. The literature on this topic, including the theoretical explanation for the use of stock options, is reviewed in section 2 . Section 3 presents the effective tax rate for a stylized VC-funded entrepreneurial firm that uses employee stock options to compensate founders, hired CEOs, and other key personnel. Section 3 also presents our measures of $\mathrm{VC}$ activity and innovative entrepreneurship. Section 4 presents cross-country regressions of the effective tax rate and $\mathrm{VC}$ activity, and explores the robustness of our results. We also present results using other indicators of entrepreneurship. Last, section 5 discusses policy implications and concludes the paper.

\section{The use of stock options in innovation finance}

Achieving success in innovative entrepreneurship is lucrative but also difficult and rare. Innovative firms must overcome technological complexity, uncertainty, high initial investment costs, and fierce competition from incumbent firms. The entrepreneur can generate more economic activity when leveraged by other complementary actors in an appropriately composed support structure. Therefore, entrepreneurial firms tend to require resources from a support structure of financial and human capital. Moreover, innovative startups and other types of Schumpeterian entrepreneurship (Schumpeter 1934 [1911]) differ significantly in their behavior and tax responsiveness from self-employment and small-firm activities (e.g., Keuschnigg and Nielsen 2004; Chetty et al. 2011; Kanniainen and Panteghini 2013). ${ }^{2}$

When other institutional and technological prerequisites for entrepreneurship are in place, VC can provide a significant boost. The exogenous expansion in $\mathrm{VC}$ funding has been shown to significantly increase innovation and entrepreneurial activity (Kortum and Lerner 2000; Gompers and Lerner 2001). Cross-country studies also show that $\mathrm{VC}$ is positively associated with business creation (Popov and Roosenboom 2013). In economies with active VC markets, VC-backed firms constitute a

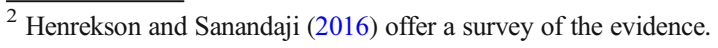

significant share of entrepreneurial successes. A majority of the firms that are sufficiently successful and go public in the USA have received VC funding (Kaplan and Lerner 2010). The same is true for approximately two fifths of IPOs in China (Guo et al. 2015). Moreover, $\mathrm{VC}$ funding is estimated to be about twice the size of funding provided by angel investors in the USA (Edelman et al. 2017).

VC-backed deals in the USA almost always use stock options in the form of call options on the common stock of a company (Gilson and Schizer 2003; Kaplan and Strömberg 2003). VC firms typically invest in the form of convertible equity to secure priority in case of bad performance, and to achieve more favorable tax treatment for the entrepreneur and other portfolio company employees. VC-backed firms also rely heavily on stock options to compensate CEOs and other employees (Bengtsson and Hand 2011, 2013).

The widespread use of these contracts has inspired a sizable body of literature. The popularity of stock options and convertible equity in VC-backed deals is believed to be fairly well explained by economic theory. The allocation of control rights follows the theoretical prediction of the incomplete contracting approach in agency theory (Holmström 1979; Grossman and Hart 1986; Hart and Moore 1990; Aghion and Bolton 1992). An influential study by Kaplan and Strömberg (2003) shows that contracts separately allocate control rights, including cash flow rights, board rights, voting rights, and liquidation rights.

Entrepreneurial finance is characterized by great uncertainty and high transaction costs (Kaplan and Strömberg 2003; Repullo and Suarez 2004; Cumming 2005b; Lerner and Schoar 2005; Kaplan et al. 2007; Cumming 2012). Assets are relationship specific (Caballero 2007), with success hinging on successful cooperation between investors and founders. Therefore, contracts must deal with adverse selection, moral hazard, and monitoring costs in a setting with high levels of uncertainty and ambiguity over future outcomes. In this environment, contingent contracts have evolved to mitigate agency problems and to align the interests of founders and investors. However, the use of stock options is less common outside the USA (Hege et al. 2003; Kaplan et al. 2007). There is no consensus on why this is the case, but proposed reasons include tax treatment and learning over time by sophisticated US VC firms.

Kaplan et al. (2007) compare VC investment contracts in 23 countries with the corresponding contracts in 
the USA, distinguishing between countries with favorable and unfavorable taxation of stock option gains. They do not find any significant difference in the use of stock options and vesting as a result of tax differences. While they examine the form of compensation in existing contracts, our concern here is to explain cross-country differences in VC activity. Cumming (2005a, b) observed a panel of Canadian firms over time and found that the reduction of taxes increased the use of stock options. Lerner and Schoar (2005) found that capital structures are influenced by the rule of law and the institutional quality of security regulations. Common-law countries have better performing VC sectors and more frequently employ convertible securities.

The evolution of the US VC industry offers some preliminary evidence of the role of taxation. In 1969, the US capital gains tax was sharply increased, and tax liabilities on employee stock options were imposed when the options were exercised instead of when the stock was sold. As a result, the VC industry declined sharply during the 1970s. The response to the decline included a series of tax cuts and institutional changes. First, the capital gains tax was lowered to $28 \%$ in 1978 , followed by a further reduction to $20 \%$ in 1981 . In addition, the latter reduction came with the possibility to defer any tax liability to the time when the stocks were sold instead of when the options were exercised. Moreover, in 1979, pension funds could invest in securities issued by small and new firms and VC funds. Following these changes, the US VC industry began to grow rapidly (Fenn et al. 1995; Henrekson and Rosenberg 2001). Studies covering other countries also find that lower capital gains taxes promote VC activity (Gompers and Lerner 1999; Jeng and Wells 2000; Armour and Cumming 2006).

Our paper focuses on developed countries, and among this group of countries, institutional quality (rule of law, property rights protection, political stability, voice, accountability, etc.) tends to be high. Nevertheless, there are large differences in the size of the VC sectors within this group of countries. In addition, there are a priori reasons, backed by US evidence, that the use of stock options is an important instrument for venture capitalists, boosting both supply and demand for VC. We hypothesize that differences in income taxation of stock options are an important determinant of the use of stock options and the size of the VC sector, which in turn fosters entrepreneurship.
An entrepreneurial firm typically lacks the necessary capital to compensate its employees using highly taxed cash compensation alone. By issuing convertible preferred stock to VC firms, a more favorable tax treatment for the entrepreneur, the CEO, and other key employees can be obtained. In the USA, the latter group is given claims on common stock for which the IRS permits the company to assign an artificially low value at the time of investment. As a result, the employee suffers negligible tax consequences upon granting or exercising the option. The tax liability can be deferred until the shares are eventually sold, and then the low capital gains rate applies (Gilson and Schizer 2003).

Thus far, this section has focused on the role of taxation to explain cross-country differences in VC sector size; however, other complementary explanations are also important. Grilli et al. (2018) studied the role of formal and informal institutions for the development of VC activity in 18 European countries. They found that formal institutional and policy variables such as taxes and regulations play an important role, and that informal social capital has an indirect effect by shaping the formation of formal institutions. Li and Zahra (2012) found a positive cross-country link between institutional quality and VC activity in a sample of both developing and developed countries.

Finally, we note that crowdfunding is a new source of entrepreneurial financing. While the USA is the leading country for VC financing, the UK has emerged as the leading country for equity crowdfunding, which had grown to $16 \%$ of the seed- and venture-stage equity investment in 2015 (Estrin et al. 2018).

There are several similarities between $\mathrm{VC}$ and equity crowdfunding. In both cases, mediating mechanisms must be developed to resolve agency and incentive problems between investors with "smart money" and entrepreneurs. Crowdfunding also uses sophisticated methods to generate dynamic information flows (Vismara 2017). The aggregation involves information cascades. As in VC financing, the reputation of the entrepreneur is evaluated by skilled investors with specialized skills in the particular industries (Polzin et al. 2016; Vismara 2017). Crowdfunding may play a bigger role for smaller firms and sectors where the availability of VC is limited (Polzin et al. 2016). In particular, crowdfunding has taken off to a much greater extent in the UK than in continental Europe, in part due to a more favorable regulatory environment that also includes a more supportive tax regime. Similar to venture capital, 
the tax regime appears to affect the development of equity crowdfunding as a source of entrepreneurial finance (Estrin et al. 2018).

\section{The effective tax rates on stock options, and measures of $\mathrm{VC}$ activity and innovative entrepreneurship}

A major challenge when analyzing the effects of stock option taxes on VC activity is that tax rates on employee stock options across countries are not easily compared. The statutory tax rate rarely reflects the true rate, which depends on a myriad of complex rules. Moreover, there is no single tax rate, with the effective tax rate depending, inter alia, on the type of firm. To reliably compare countries, we constructed a representative firm and commissioned the global accounting firm PricewaterhouseCoopers $(\mathrm{PwC})$ to calculate the tax rate for employee stock options for a sample of countries. PwC specializes in tax issues and relied on their tax experts in each country to estimate the stock option tax rate for the year 2012 . Income taxes, capital gains taxes, and payroll taxes were included when possible.

Our sample consists of 22 advanced economies in the developed world. These countries are Australia, Canada, China, Denmark, Finland, France, Germany, Hong Kong, Ireland, Israel, Italy, Japan, the Netherlands, Norway, Portugal, Singapore, South Korea, Spain, Sweden, Switzerland, the UK, and the USA. VC is a complex activity that requires financial depth, strong institutions, and an advanced economy. Thus, large VC markets tend to only develop in mature economies. Therefore, we expect taxation to be an important determinant of $\mathrm{VC}$ activity solely in countries that fulfill such criteria. Lowering tax rates alone is unlikely to create VC markets. Because Eastern European countries lack the mature financial sectors and the strong property and contractual rights required for a large $\mathrm{VC}$ sector, these countries are excluded from further analyses.

The small sample size is due to the high costs of having PwC calculate effective option taxes in each country, which limits the statistical power of our analysis. In Henrekson and Sanandaji (2018), we added 16 industrialized countries to the sample using our own calculations of effective option taxes; although our calculations differ from the $\mathrm{PwC}$ method, expanding the sample produced similar results as found in the smaller sample of 22 countries used here.
The effective tax rate is modeled in line with the analysis by Gilson and Schizer (2003), and calculated for the following case or scenario. We strive to keep the scenario as simple as possible while retaining all essential characteristics of a typical VC deal. The representative firm is founded in a home or an incubator by a founder with little initial capital needs. After 1 year of growth, a further expansion requires an equity infusion that the founder is unable to meet. A VC firm buys the entire firm, simultaneously giving the founder the option to buy back $25 \%$ of the firm after 7 years. The options are priced as the nominal stock value of the firm that applies at year 1, which is negligible. After 3 years, a CEO is hired. He or she is given the option to purchase $10 \%$ of the firm. At this point, the firm is valued at USD 5 million. After 8 years, the firm is bought for USD 20 million in a trade sale. Immediately before the sale, the stock options are exercised and the founder and CEO come to possess $35 \%$ or USD 7 million worth of stock, which they sell to the purchasing firm.

For some countries, there exist alternative and more favorable tax rates under the representative firm scenario, given that certain additional requirements are fulfilled. When this applies, we rely on the alternative lower tax rate that real-life firms are likely to utilize. Table 1 reports the tax rates that were calculated by PwC's tax experts. The tax rates are reported as a share of total compensation, and any payroll taxes are assumed to fall on the recipient of the option. ${ }^{3}$

Although the calculated tax rates cannot be said to apply automatically to all entrepreneurial firms, we deem that the representative firm is a sufficiently good proxy for the general transaction costs associated with stock option taxation for entrepreneurship.

A more common way to estimate tax rates on capital gains on equity is to rely on statutory corporate and individual capital gains taxes. This method is simpler and enables a larger sample size of countries and periods, but it introduces measurement problems because the effective tax rate often differs significantly from the statutory rate. The preferred method would be using the actual tax rate for a large sample of countries over time.

\footnotetext{
$\overline{3}$ The estimated tax rates include all taxes that are levied in our scenario. This could include corporate taxes for the firm if the firm's cost of issuing stock options is not tax deductible, mandatory social security contributions to be paid by the grantor and/or the employee, and income taxes to be paid by the grantee. In some cases, it could be the regular marginal income tax rate on labor income. In other cases, it could just be the capital gains tax at the time of final sale of the received stock. It could also be a combination of the two types of taxes.
} 
Table 1 Effective tax rate on stock options and VC activity as a share of GDP in 2012

\begin{tabular}{lll}
\hline Country & Tax rate $(\%)$ & VC activity, \% of GDP \\
\hline Australia & 24.8 & 0.016 \\
Canada & 31.9 & 0.138 \\
China & 45.0 & 0.028 \\
Denmark & 55.3 & 0.104 \\
Finland & 51.3 & 0.058 \\
France & 29.9 & 0.042 \\
Germany & 47.5 & 0.025 \\
Hong Kong & 15.0 & 0.069 \\
Ireland & 7.4 & 0.068 \\
Israel & 25.0 & 0.195 \\
Italy & 72.2 & 0.009 \\
Japan & 50.5 & 0.004 \\
Netherlands & 25.0 & 0.032 \\
Norway & 50.8 & 0.034 \\
Portugal & 56.5 & 0.041 \\
Singapore & 20.0 & 0.021 \\
South Korea & 61.5 & 0.021 \\
Spain & 52.0 & 0.011 \\
Sweden & 54.3 & 0.071 \\
Switzerland & 51.5 & 0.047 \\
UK & 28.0 & 0.088 \\
USA & 15.0 & 0.196 \\
\hline Source: Pricewater & & \\
\hline
\end{tabular}

Source: PricewaterhouseCoopers $(\mathrm{PwC})$ and Thomson One

As an auxiliary exercise, we report results from a panel regression using the statutory tax rates by relying on the data reported by Dhaliwal et al. (2014). In that study, the authors report mean statutory tax rates for both corporate and capital gains taxes for 33 countries between 1992 and 2012, which are averaged over three 7-year periods (1992-1998, 1999-2005, and 20062012). We use VC investment as reported by Thomson One in the same period, which was also averaged over the same 7-year intervals.

In the main cross-sectional regression, we rely on the Thomson One database for the rate of VC activity (measured as the total sum of $\mathrm{VC}$ investments) as a share of GDP in 2012. The preferred outcome variable would have been $\mathrm{VC}$ investments that use stock options rather than all $\mathrm{VC}$ activity. To our knowledge, there are no systematic cross-country data enabling the construction of such a measure. Thus, we report results for the entire VC sector.
To further explore whether stock option taxation is a determinant of innovative entrepreneurship (which is the main target of venture capitalists), we apply two other measures of entrepreneurship as dependent variables. First, an alternative measure of innovative entrepreneurship, namely high-growth expectation total early-stage entrepreneurial activity (High TEA). High TEA measures the share of all new firms where the founders expect to employ at least 5 employees 5 years from now. This measure is collected by the Global Entrepreneurship Monitor using annual surveys (Singer et al. 2015). The share of High TEA ranges from $15 \%$ in Italy to $51 \%$ in Singapore, with a median of $26 \%$. The second measure consists of new firms where the founders do not expect to employ five employees or more within 5 years. This is referred to as low-growth expectation total early-stage entrepreneurial activity (Low TEA).

Option taxes and VC activity as a share of GDP are based on 2012 figures. High TEA and Low TEA are based on 2012 for most countries, but for seven countries, this is replaced with the average for available years from 2008 to 2014 when the data were missing for 2012. Covariates are similarly based on 2012 when possible, although in a few cases, they are replaced by the average for 2008 to 2014 when there are missing observations. This allows for a full sample for all variables.

\section{Regression results}

Table 2 presents the definitions and sources of the variables used. Table 3 presents the correlations between the dependent and independent variables used in the regression analyses.

In our regressions, we add control variables that are available in a cross-country setting and likely related to VC activity, entrepreneurship, and taxes. R\&D spending as the share of GDP controls for innovation and includes both private and public spending. PPP-adjusted GDP per capita is a standard control. Market capitalization of all listed firms as a share of GDP controls for the level of financial sophistication. In previous versions of this study, we included the country-level shares of tertiary education, the World Bank index of regulation, and the World Bank profit tax on small businesses. These control variables were dropped because they had little or no impact on the results. 
Table 2 Variable definitions

\begin{tabular}{|c|c|c|}
\hline Variable & Definition & Source \\
\hline VC/GDP & VC investment as a share of GDP in 2012 & Thomson Reuters \\
\hline Option tax & Harmonized effective tax rate on stock option gains in 2012 & PwC (see text for details) \\
\hline $\begin{array}{l}\text { Capital tax } \\
\text { rate }\end{array}$ & $\begin{array}{l}\text { Combined statutory corporate and individual capital gains tax rates, } \\
1992-2012\end{array}$ & Dhaliwal et al. (2014) \\
\hline GDP/cap & PPP-adjusted GDP per capita in 2012 & IMF, http://www.imf.org/external/data.htm \\
\hline Revenue/GDP & General government revenue as a share of GDP in 2012 & IMF, http://www.imf.org/external/data.htm \\
\hline $\mathrm{R} \& \mathrm{D} / \mathrm{GDP}$ & R\&D expenditure as a share of GDP in 2012 & World Bank, http://www.doingbusiness.org/data \\
\hline $\begin{array}{l}\text { Market } \\
\text { cap/GDP }\end{array}$ & Market capitalization of all listed firms as a share of GDP in 2012 & World Bank, http://www.doingbusiness.org/data \\
\hline TEA & $\begin{array}{l}\text { Total entrepreneurial activity, share of population aged 18-64 in the } \\
\text { process of creating a new business or running a business less than } \\
3.5 \text { years old in } 2012\end{array}$ & $\begin{array}{l}\text { Global Entrepreneurship Monitor Annual Reports, } \\
\text { 2008-2014, http://www.gemconsortium. } \\
\text { org/report }\end{array}$ \\
\hline High TEA & Subgroup of TEA in 2012 expecting to employ $\geq 5$ people in 5 years & See TEA \\
\hline Low TEA & Subgroup of TEA in 2012 expecting to employ $<5$ people in 5 years & See TEA \\
\hline
\end{tabular}

The World Bank data that we use were collected within the Doing Business project, which published its first report in 2004 (World Bank 2015). The variables used in the longitudinal regressions reported in Table 5 are the same as those above but cover the years from 1992 to 2012. In a few cases, when values for 2012 were missing in the World Bank databases, the 2008-2014 average was used for High TEA, Low TEA, Market cap/GDP, and Revenue/GDP

It is possible that the overall tax rate rather than the option tax rate determines VC activity, and that countries with high tax rates overall also tend to have high option and capital tax rates. Therefore, we control for government revenue as a share of GDP in the crosscountry regressions.

VC activity is positively correlated with High TEA and negatively correlated with option taxes rates. There is weaker and ambiguous correlation with Low TEA, $\mathrm{R} \& \mathrm{D}$ investment as a share of GDP, and the market capitalization of listed firms as a share of GDP and GDP per capita.

Table 4 presents our main regression estimates, which show a negative association between option tax and VC activity. Notwithstanding that the lack of an exogenous variation of tax rates precludes a causal inference, and that the small sample size hampers the statistical power, we find a strong negative correlation between tax rates and $\mathrm{VC}$ activity. This is consistent with the view that high option tax rates reduce $\mathrm{VC}$ backed entrepreneurship.

The option tax is measured in percentage. Therefore, an increase from 20 to $21 \%$ represents a one-unit increase in the tax rate. In all specifications, a $10 \%$ point increase in the option tax rate is associated with a decrease in VC activity of approximately $0.015 \%$ of GDP, or around one fourth in the median country. R\&D spending as a share of GDP is also positively associated with VC activity. The median country spends 2 percentage points of GDP on R\&D. An increase by 1 percentage point (roughly $50 \%$ for the average country) is associated with an increase in VC activity of approximately $0.025 \%$ of GDP. This indicates that the effect of $\mathrm{R} \& \mathrm{D}$ spending is roughly comparable in magnitude to the effect of the option tax. The other control variables are not statistically significant, which is likely due to the small sample size and the fact that the regressions are performed for one single year. While some controls are stable, others are sensitive to the year used for smaller countries. In particular, market capitalization of listed firms as a share of GDP dropped sharply in many countries following the financial crisis.

Table 5 reports the results from the fixed-effect regression for the panel of 33 countries from Dhaliwal et al. (2014). ${ }^{4}$ The results show a negative association between capital taxes and VC investment over time. For variables with longer series available, dating back to 1992, we added the same control variables as in the

\footnotetext{
${ }^{4}$ The sample consists of the following 33 countries: Argentina, Australia, Austria, Belgium, Canada, Denmark, Finland, France, Germany, Hong Kong, India, Indonesia, Ireland, Italy, Japan, Korea, Malaysia, Mexico, the Netherlands, New Zealand, Norway, Philippines, Portugal, Singapore, South Africa, Spain, Sweden, Switzerland, Taiwan, Thailand, Turkey, the UK, and the USA. The results are qualitatively similar if we instead use the same 22 countries as in the cross-sectional regressions.
} 
Table 3 Correlation matrix of variables used

\begin{tabular}{|c|c|c|c|c|c|c|c|}
\hline & VC/GDP & Option tax & GDP/capita & $\mathrm{R} \& \mathrm{D} / \mathrm{GDP}$ & Market cap/GDP & Revenue/GDP & High TEA \\
\hline Option tax & $-0.43 * *$ & & & & & & \\
\hline GDP/capita & 0.02 & -0.34 & & & & & \\
\hline R\&D/GDP & 0.28 & 0.22 & -0.09 & & & & \\
\hline Market cap/GDP & 0.05 & $-0.38^{*}$ & 0.30 & -0.35 & & & \\
\hline Revenue/GDP & -0.01 & 0.36 & -0.01 & 0.02 & $-0.47 * *$ & & \\
\hline High TEA & $0.37 *$ & $-0.54 * *$ & -0.02 & -0.12 & 0.27 & $-0.64 * *$ & \\
\hline Low TEA & 0.25 & -0.05 & -0.34 & 0.01 & $-0.37 *$ & -0.11 & $0.57 * *$ \\
\hline
\end{tabular}

$*$ and $* *$ denote significance at 10 and $5 \%$, respectively

previous regressions. The estimated effect of the integrated statutory capital tax rate remains largely unchanged when controlling for GDP per capita, government revenue, market capitalization of listed firms, and $R \& D$ investment. To reject that the estimated effect is driven solely by the USA, we also tested to exclude the US from the sample. This results in a smaller but still statistically significant coefficient. $R \& D$ spending as a share of GDP has a positive association, although it is not statistically significant.

Interestingly, the integrated statutory capital tax rate is negatively associated with VC activity in a fixedeffect setting but not in cross-sectional analyses. While this relationship is somewhat sensitive to the sample of countries and control variables used, it is fairly consistent. This is in line with the results from Henrekson and Sanandaji (2018). When contrasting the cross-sectional correlation of $\mathrm{VC}$ activity with the two methods of calculating tax rates, a negative association only emerges for the effective option tax rate. This could suggest that the use of statutory tax rates in crosscountry settings leads to spurious results, although the bias is addressed in the fixed-effect analyses that use the variations over time within countries. In particular, the USA and several other countries have a high formal corporate tax rate but a low effective tax rate on $\mathrm{VC}$ investors.

We run further regressions on High TEA (as a measure of innovative entrepreneurship) and Low TEA (as a measure of non-innovative entrepreneurship) using the

Table 4 Cross-country regressions of VC activity as a share of GDP and the option tax rate

\begin{tabular}{|c|c|c|c|c|c|}
\hline & (1) & (2) & (3) & (4) & (5) \\
\hline Option tax & $\begin{array}{l}-0.133 * * \\
(0.064)\end{array}$ & $\begin{array}{l}-0.149 \text { ** } \\
(0.070)\end{array}$ & $\begin{array}{l}-0.171 * \\
(0.076)\end{array}$ & $\begin{array}{l}-0.202 * * \\
(0.072)\end{array}$ & $\begin{array}{l}-0.198 * * \\
(0.086)\end{array}$ \\
\hline GDP/capita & & $\begin{array}{c}-0.058 \\
(0.083)\end{array}$ & $\begin{array}{c}-0.068 \\
(0.078)\end{array}$ & $\begin{array}{c}-0.066 \\
(0.056)\end{array}$ & $\begin{array}{l}-0.082 \\
(0.056)\end{array}$ \\
\hline Revenue/GDP & & & $\begin{array}{l}0.094 \\
(0.082)\end{array}$ & $\begin{array}{l}0.108 \\
(0.084)\end{array}$ & $\begin{array}{l}0.145 \\
(0.103)\end{array}$ \\
\hline $\mathrm{R} \& \mathrm{D} / \mathrm{GDP}$ & & & & $\begin{array}{l}2.374 * * \\
(1.038)\end{array}$ & $\begin{array}{l}2.670 * * \\
(1.090)\end{array}$ \\
\hline Market capitalization/GDP & & & & & $\begin{array}{l}0.416 \\
(0.387)\end{array}$ \\
\hline Constant & $\begin{array}{l}11.27 * * * \\
(3.33)\end{array}$ & $\begin{array}{l}14.35 * * \\
(5.90)\end{array}$ & $\begin{array}{l}12.000 * \\
(5.96)\end{array}$ & $\begin{array}{l}7.06^{*} \\
(4.06)\end{array}$ & $\begin{array}{l}4.94 \\
(5.54)\end{array}$ \\
\hline Observations & 22 & 22 & 22 & 22 & 22 \\
\hline$R$-squared & 0.19 & 0.20 & 0.23 & 0.39 & 0.40 \\
\hline
\end{tabular}

The table reports ordinary least square cross-sectional regressions with robust standard errors where the dependent variable is VC investment as a share of GDP in 2012. Because VC activity is a small share of GDP, it is expressed as dollars in VC investment per USD 10,000 units of GDP. Thus, each unit represents $0.01 \%$ of GDP

$* * * p<0.01 ; * * p<0.05 ; * p<0.1$ 
Table 5 Cross-country fixed-effect panel regressions of VC activity as a share of GDP and the integrated statutory capital tax rate (19922012)

\begin{tabular}{|c|c|c|c|c|c|}
\hline & (1) & (2) & (3) & (4) & (5) \\
\hline Capital tax rate & $\begin{array}{l}-0.26^{* * *} \\
(0.085)\end{array}$ & $\begin{array}{l}-0.23^{* *} \\
(0.097)\end{array}$ & $\begin{array}{l}-0.24 * * * \\
(0.088)\end{array}$ & $\begin{array}{l}-0.23 * * \\
(0.093)\end{array}$ & $\begin{array}{l}-0.24 * * \\
(0.093)\end{array}$ \\
\hline GDP/capita & & $\begin{array}{l}0.029 \\
(0.043)\end{array}$ & $\begin{array}{l}0.022 \\
(0.047)\end{array}$ & $\begin{array}{l}-0.002 \\
(0.063)\end{array}$ & $\begin{array}{l}-0.013 \\
(0.065)\end{array}$ \\
\hline Revenue/GDP & & & $\begin{array}{l}-0.41^{* *} \\
(0.185)\end{array}$ & $\begin{array}{l}-0.40 * * \\
(0.181)\end{array}$ & $\begin{array}{l}-0.47^{* *} \\
(0.178)\end{array}$ \\
\hline $\mathrm{R} \& \mathrm{D} / \mathrm{GDP}$ & & & & $\begin{array}{l}0.019 \\
(0.019)\end{array}$ & $\begin{array}{l}0.012 \\
(0.019)\end{array}$ \\
\hline Market capitalization/GDP & & & & & $\begin{array}{l}0.013^{* *} \\
(0.006)\end{array}$ \\
\hline Constant & $\begin{array}{l}15.95 * * * \\
(3.46)\end{array}$ & $\begin{array}{l}14.22 * * * \\
(4.63)\end{array}$ & $\begin{array}{l}28.9 * * * \\
(8.21)\end{array}$ & $\begin{array}{l}25.87 * * * \\
(8.14)\end{array}$ & $\begin{array}{l}29.02 * * * \\
(8.36)\end{array}$ \\
\hline Observations & 99 & 99 & 99 & 99 & 99 \\
\hline$R$-squared & 0.09 & 0.09 & 0.12 & 0.13 & 0.15 \\
\hline
\end{tabular}

Robust standard errors in parentheses. The regressions are fixed-effect regressions over time for the period from 1992 to 2012 for 33 countries, measured as the average over the periods 1992-1998, 1999-2005, and 2006-2012, respectively. The tax variable is defined as the combined statutory corporate and individual capital gains tax rate. Because VC activity is a small share of GDP, it is expressed as dollars in VC investment per USD 10,000 units of GDP. Thus, each unit represents $0.01 \%$ of GDP. In median countries in our sample, VC investment was approximately $0.05 \%$ of GDP, peaking at approximately $0.2 \%$ in the USA and Hong Kong. The tax rate is measured as a percentage, so that an increase from 20 to $21 \%$ represents a one-unit increase in the tax rate

$* * * p<0.01 ; * * p<0.05 ; * p<0.1$

same controls as in previous regressions. The results for High TEA are presented in Table 6. Just as with VC activity, the option tax is negatively and significantly associated with High TEA. In contrast, the same regressions with Low TEA as the dependent variable show no link with the option tax rate. (Results are available on request.) This is consistent with the fact that Low TEA is an indicator of low-impact entrepreneurship rather than high-impact/Schumpeterian entrepreneurship.

Thus, the empirical analyses indicate that a low option tax rate is positively associated with the size of the VC sector and high-growth expectation total early-stage entrepreneurial activity. Even if we were to interpret these links as causal, this would not identify the underlying mechanism. However, one possible mechanism is that a lower option tax only increases entrepreneurship through VC activity. Another plausible explanation is that a low option tax rate stimulates similar firms that do not use VC by raising the expected returns for founders and other equity owners.

Establishing the mechanism between the option tax and entrepreneurial activity requires a more extensive empirical framework than our simple cross-country comparisons. However, from the vantage point of European policymakers, it is of secondary importance whether a lower taxation of gains on stock options boosts entrepreneurship because it increases the supply of entrepreneurial effort and thus the demand for $\mathrm{VC}$, or because it increases the supply of $\mathrm{VC}$, or because of a combination of these two effects. As long as such a tax cut boosts Schumpeterian entrepreneurship, the underlying mechanism causing the desired effect on innovation-based entrepreneurship belongs to further research.

\section{Discussion and conclusions}

The modern VC sector first emerged in the USA and it remains the country that has the world's largest VC sector. In fact, the US VC sector is larger than that of the rest of the world combined (Lerner and Tåg 2013). VC activity is far smaller in most European countries, despite high rates of R\&D spending and a high per capita income. Experience from the US VC sector indicates that convertible equity and stock options are widely used when these instruments are advantageous from a tax perspective. This is likely because the contractual design of these financial instruments constitutes a good fit for the complex challenges facing the VC-funded 
Table 6 Cross-country regressions of High TEA and the option tax rate in 2012

\begin{tabular}{|c|c|c|c|c|c|}
\hline & (1) & $(2)$ & (3) & (4) & $(5)$ \\
\hline Option tax & $\begin{array}{l}-0.037 * * * \\
(0.011)\end{array}$ & $\begin{array}{l}-0.041 * * * \\
(0.012)\end{array}$ & $\begin{array}{l}-0.028^{* * *} \\
(0.010)\end{array}$ & $\begin{array}{l}-0.027 * * \\
(0.011)\end{array}$ & $\begin{array}{l}-0.028 * * \\
(0.012)\end{array}$ \\
\hline GDP/capita & & $\begin{array}{l}-0.017 \\
(0.017)\end{array}$ & $\begin{array}{l}-0.012 \\
(0.012)\end{array}$ & $\begin{array}{l}-0.012 \\
(0.012)\end{array}$ & $\begin{array}{l}-0.008 \\
(0.011)\end{array}$ \\
\hline Revenue/GDP & & & $\begin{array}{l}-0.055^{* * *} \\
(0.014)\end{array}$ & $\begin{array}{l}-0.056^{* * * *} \\
(0.015)\end{array}$ & $\begin{array}{l}-0.064 * * * \\
(0.016)\end{array}$ \\
\hline R\&D/GDP & & & & $\begin{array}{c}-0.048 \\
(0.193)\end{array}$ & $\begin{array}{l}-0.114 \\
(0.213)\end{array}$ \\
\hline Market capitalization/GDP & & & & & $\begin{array}{c}-0.093 \\
(0.057)\end{array}$ \\
\hline Constant & $\begin{array}{l}3.685 * * * \\
(0.511)\end{array}$ & $\begin{array}{l}4.581 * * * \\
(1.010)\end{array}$ & $\begin{array}{l}5.969 * * * \\
(0.903)\end{array}$ & $\begin{array}{l}6.069 * * * \\
(1.017)\end{array}$ & $\begin{array}{l}6.539 * * * \\
(1.194)\end{array}$ \\
\hline Observations & 22 & 22 & 22 & 22 & 22 \\
\hline$R$-squared & 0.297 & 0.329 & 0.329 & 0.340 & 0.561 \\
\hline
\end{tabular}

This table reports ordinary least square cross-sectional regressions with robust standard errors where the dependent variable is the share of TEA in 2012 expecting to employ $\geq 5$ people in 5 years

$* * * p<0.01 ; * * p<0.05 ; * p<0.1$

entrepreneurial sector. Therefore, the effective tax treatment of option contracts may be a major determinant of the size of the VC-funded entrepreneurial sector.

Taxes, most notably taxes on stock options, are not the only explanation for cross-country differences in VC activity or broader innovative business activity. The USA and continental European countries, such as Germany, represent different varieties of capitalism with major differences in ownership structures, financing methods, the role of banks, ownership groups, and other characteristics (Dilli et al. 2018). In part, the observed differences between tax rates and the level of $\mathrm{VC}$ activity reflect more fundamental economic differences; even if the role of stock option taxes for VC activity is correctly identified in the USA, this may not guarantee that lowering these taxes would have a similar effect in Europe. Nevertheless, Europe has moved toward the US model of financing and developing innovation-based entrepreneurial ventures, partly because of the seemingly superior performance of this model. In addition, the likely importance of stock option taxation is reinforced by the fact that our results still hold when excluding the USA.

The favorable tax treatment for the entrepreneur and other employees with stock options in the USA was not initially planned but emerged as the VC sector gradually developed its contractual model. A major advantage is that this policy narrowly targets the entrepreneurial sector rather than entailing broad tax cuts. Gilson and Schizer (2003, p. 878) write that "[a]s a practical matter, only companies that can attract venture capital investment receive this tax subsidy." US tax policy does not explicitly connect the employee's tax treatment to the use of convertible preferred equity and stock options. Instead, the favorable tax treatment is part of tax practice. Although this policy was unintentional, we argue that it has nevertheless developed into one of the most efficient ways to intentionally promote entrepreneurship. The reason is that such tax breaks target startups receiving $\mathrm{VC}$ funding, which is a small but strategic sector of the economy. The policy lowers the effective taxation of startups that are screened by venture capitalists willing to invest their own funds, without requiring the government to determine which firms are entrepreneurial.

Another major benefit is that innovative startups can be given a tax break without the need for broad capital gains tax cuts. Innovative startups that can be classified as Schumpeterian entrepreneurship constitute a small fraction of both new and currently active firms. Most new firms are best described as "mom-and-pop" operations without the ambition to grow or innovate (Shane 2008; Hurst and Pugsley 2011; Henrekson and Sanandaji 2014). It is difficult to ex ante separate innovative startups from non-entrepreneurial self-employment. However, VC-funded firms tend to represent a large segment of the truly innovative firms that are screened by skilled professionals. Although a mere 0.1 to $0.2 \%$ of all firms in the US receive early-stage 
financing from venture capitalists (Puri and Zarutskie 2012), these VC-funded firms constitute the majority of firms that are successful enough to go public. Therefore, a tax break that targets human capital in this segment is an effective way to promote innovative entrepreneurship without incurring the high fiscal cost of broad capital gains tax cuts.

There is also a more subtle reason why lower taxes on employee stock options is preferable to broad tax cuts as a means to promote entrepreneurship. It is not only the absolute tax rate that matters - taxes relative to other sectors also matter. Entrepreneurial startups are extremely important for growth and renewal, but they only constitute a small share of the entire stock of financial and human capital. Entrepreneurial firms compete for investments and talent with other sectors of the economy including large incumbent firms but also academia, non-entrepreneurial small businesses, non-profit organizations, and the government. In the case of high taxes, capital might be invested passively in the stock market or not invested at all, rather than in entrepreneurial firms. Broad-based capital gains taxes do not shift capital from passive investments to private equity, unlike tax breaks on stock options and other instruments widely used by the VC sector.

Perhaps most importantly, the existence of favorable tax treatment for the entrepreneur and other employees with employee stock options shifts talent to the innovative entrepreneurial sector. Recent research has shown that the effect of owner-level taxes on occupational choice is of first-order importance (Henrekson and Sanandaji 2016). Potentially successful entrepreneurs are rare and tend to have well-paid jobs and career opportunities in incumbent firms. The risk of failure is large and most of the aggregate returns are concentrated to a few successful cases. To attract a sufficient number of talented people who are willing to incur these opportunity costs and assume the risks involved, economic incentives must be sufficiently strong. Broad-based tax cuts on all income earners will be less potent in making it more attractive to found or work for a startup, while resulting in far larger reductions in tax revenue.

This may help explain why the US and other countries with lower tax rates on employee stock options have larger VC sectors as a share of GDP. This policy helps the VC sector compete for limited resources within each country, including top talent, which in turn awards the VC sector of the country a competitive advantage relative to that of other nations.
We have argued that the possibility of using stock options to reward entrepreneurial effort is affected by the tax code. This would suggest that the rules pertaining to the granting of and gains on employee stock options are likely to inhibit innovative entrepreneurship in Western Europe. Entrepreneurial startups are of disproportionate importance for innovation and renewal, but because they only constitute a small share of the economy, they are of minor importance as a source of government revenue. A well-designed reform of the taxation of stock options and similar instruments, along the lines of the US reforms implemented around 1980, would result in a negligible loss of tax revenue in the short run, and likely be lucrative in the long run. Consequently, it would be a cost-efficient reform for improving the European ecosystem for entrepreneurial firms.

Acknowledgements We are grateful for the useful comments and suggestions from Victor Ahlqvist, Simon Ek, Saul Estrin, Steven Kaplan, Vesa Kanniainen, Werner Liebregts, and David Schizer and two anonymous referees. This study was written as part of the EU project Financial and Institutional Reforms for the Entrepreneurial Society (FIRES) (Grant Agreement Number 949378). We also gratefully acknowledge financial support from the Jan Wallander and Tom Hedelius Foundation and from the Marianne and Marcus Wallenberg Foundation.

Open Access This article is distributed under the terms of the Creative Commons Attribution 4.0 International License (http:// creativecommons.org/licenses/by/4.0/), which permits unrestricted use, distribution, and reproduction in any medium, provided you give appropriate credit to the original author(s) and the source, provide a link to the Creative Commons license, and indicate if changes were made.

\section{References}

Aghion, P., \& Bolton, P. (1992). An incomplete contracts approach to financial contracting. Review of Economic Studies, 59(3), 473-494. https://doi.org/10.2307/2297860.

Armour, J., \& Cumming, D. (2006). The legislative road to Silicon Valley. Oxford Economic Papers, 58(4), 596-635. https://doi.org/10.1093/oep/gp1007.

Åslund, A., \& Djankov, S. (2017). Europe's growth challenge. New York: Oxford University Press.

Bascha, A., \& Walz, U. (2001). Convertible securities and optimal exit decisions in venture capital finance. Journal of Corporate Finance, 7(3), 285-306. https://doi.org/10.1016 /S0929-1199(01)00023-2.

Bengtsson, O., \& Hand, J. (2011). CEO compensation in venturebacked firms. Journal of Business Venturing, 26(4), 391-411. https://doi.org/10.1016/j.jbusvent.2009.11.001. 
Bengtsson, O., \& Hand, J. (2013). Employee compensation in entrepreneurial companies. Journal of Economics and Management Strategy, 22(2), 312-340.

Black, B. S., \& Gilson, R. J. (1998). Venture capital and the structure of capital markets: banks versus stock markets. Journal of Financial Economics, 47(3), 243-277. https://doi.org/10.1016/S0304-405X(97)00045-7.

Caballero, R. J. (2007). Specificity and the macroeconomics of restructuring. Cambridge, MA: MIT Press.

Chetty, R., Friedman, J., Olsen, T., \& Pistaferri, L. (2011). Adjustment costs, firm responses, and micro vs. macro labor supply elasticities: evidence from Danish tax records. Quarterly Journal of Economics, 126(2), 749-804. https://doi.org/10.1093/qje/qjr013.

Chittenden, F., Hall, G., \& Hutchinson, P. (1996). Small firm growth, access to capital markets and financial structure: review of issues and an empirical investigation. Small Business Economics, 8(1), 59-67. https://doi.org/10.1007 /BF00391976.

Cumming, D. (2005a). Agency costs, institutions, learning, and taxation in venture capital contracting. Journal of Business Venturing, 20(5), 573-622. https://doi.org/10.1016/j. jbusvent.2003.07.001.

Cumming, D. (2005b). Review essay: global venture capital transactions. Venture Capital, 7(2), 185-201. https://doi. org/10.1080/13691060500061289.

Cumming, D. (2012). Venture capital financial contracting: an overview of the international evidence. In H. Landström \& C. Mason (Eds.), Handbook of research on venture capital: volume 2. Cheltenham: Edward Elgar.

Dhaliwal, D. S., Krull, L. K., \& Li, O. Z. (2014). Tax and the cost of equity capital: an international analysis. Available at SSRN: https://ssrn.com/abstract=2402009.

Dilli, S., Elert, N., \& Herrmann, A. (2018). Varieties of entrepreneurship: exploring the institutional foundations of different entrepreneurship types through "varieties-of-capitalism" arguments. Small Business Economics, forthcoming.

Edelman, L. F., Manolova, T. S., \& Brush, C. G. (2017). Angel investing: a literature review. Foundations and Trends in Entrepreneurship, 13(4-5), 265-439. https://doi. org/10.1561/0300000051.

Elert, N., Henrekson, M., \& Stenkula, M. (2017). Institutional reform for innovation and entrepreneurship - an agenda for Europe. New York: Springer International Publishing.

Estrin, S., Gozman, D., \& Khavul, S. (2018). The evolution and adoption of equity crowdfunding: entrepreneur and investor entry into a new market, Small Business Economics. https://doi.org/10.1007/s11187-018-0009-5.

Fenn, G., Liang, N., \& Prowse, S. (1995). The economics of the private equity market. Washington, DC: Board of Governors of the Federal Reserve System.

Gilson, R. J., \& Schizer, D. M. (2003). Understanding venture capital structure: a tax explanation for convertible preferred stock. Harvard Law Review, 116(3), 874-916. https://doi. org/10.2307/1342584.

Gompers, P. A. (1997). Ownership and control in entrepreneurial firms: an examination of convertible securities in venture capital investments. Unpublished working paper, Harvard Business School.

Gompers, P. A., \& Lerner, J. (1999). An analysis of the compensation in the U.S. venture capital partnership. Journal of
Financial Economics, 51(1), 3-44. https://doi.org/10.1016 /S0304-405X(98)00042-7.

Gompers, P. A., \& Lerner, J. (2001). The money of invention: how venture capital creates new wealth. Cambridge, MA: Harvard Business School Press.

Grilli, L., Mrkajic, B., \& Latifi, G. (2018). Venture capital in Europe: social capital, formal institutions and mediation effects. Small Business Economics, https://doi.org/10.1007 /s11187-018-0009-5.

Grossman, S. J., \& Hart, O. (1986). The costs and benefits of ownership: a theory of vertical and lateral integration. Journal of Political Economy, 98(6), 1119-1158. https://doi.org/10.1086/261404.

Guo, D., Jiang, K., \& Mai, X. (2015). Venture capital investment and the post-IPO performance of entrepreneurial firms: evidence from the People's Republic of China. Asian Development Review, 32(1), 113-141. https://doi. org/10.1162/ADEV_a_00043.

Hart, O., \& Moore, J. (1990). Property rights and the nature of the firm. Journal of Political Economy, 98(6), 1119-1158. https://doi.org/10.1086/261729.

Hege, U., Palomino, F., \& Schwienbacher, A. (2003). Determinants of venture capital performance: Europe and the United States. LSE Ricafe working paper 1. London: London School of Economics and Political Science.

Henrekson, M., \& Rosenberg, N. (2001). Designing efficient institutions for science-based entrepreneurship: lessons from the US and Sweden. Journal of Technology Transfer, 26(3), 207-231. https://doi.org/10.1023/A:1011153922906.

Henrekson, M., \& Sanandaji, T. (2014). Small business activity does not measure entrepreneurship. Proceedings of the National Academy of Sciences of the United States of America (PNAS), 111(5), 1760-1765. https://doi. org/10.1073/pnas.1307204111.

Henrekson, M., \& Sanandaji, T. (2015). Superentrepreneurship and global imbalances: closing Europe's gap to other industrialized regions. In A. B. Engelbrekt, L. Oxelheim, \& T. Persson (Eds.), The EU's role in fighting global imbalances. Cheltenham: Edward Elgar.

Henrekson, M., \& Sanandaji, T. (2016). Owner-level taxes and business activity. Foundations and Trends in Entrepreneurship, 12(1), 1-101. https://doi.org/10.1561 /0300000060.

Henrekson, M., \& Sanandaji, T. (2017). Schumpeterian entrepreneurship in Europe compared to other industrialized regions. IFN working paper no. 1170. Stockholm: Research Institute of Industrial Economics.

Henrekson, M., \& Sanandaji, T. (2018). Stock option taxation and venture capital activity: a cross-country study. Venture Capital, 20, (1), 51-71.

Holmström, B. (1979). Moral hazard and observability. Bell Journal of Economics, 10(1), 74-91. https://doi.org/10.2307 13003320

Hurst, E., \& Pugsley, B. W. (2011). What do small businesses do? Brookings Papers on Economic Activity, 42(2), 73-118.

Jeng, L., \& Wells, P. (2000). The determinants of venture capital funding: evidence across countries. Journal of Corporate Finance, 6(3), 241-289. https://doi.org/10.1016/S09291199(00)00003-1.

Kanniainen, V., \& Panteghini, P. (2013). Tax neutrality: illusion or reality? The case of entrepreneurship. FinanzArchiv: Public 
Finance Analysis, 69(2), 167-193. https://doi.org/10.1628 /001522113X666926.

Kaplan, S. N., \& Lerner, J. (2010). It ain’t broke: the past, present, and future of venture capital. Journal of Applied Corporate Finance, 22(2), 36-47.

Kaplan, S. N., \& Strömberg, P. (2003). Financial contracting theory meets the real world: evidence from venture capital contracts. Review of Economic Studies, 70(2), 281-315. https://doi.org/10.1111/1467-937X.00245.

Kaplan, S. N., Martel, F., \& Strömberg, P. (2007). How do legal differences and experience affect financial contracts? Journal of Financial Intermediation, 16(3), 273-311. https://doi. org/10.1016/j.jfi.2007.03.005.

Keuschnigg, C., \& Nielsen, S. B. (2004). Start-ups, venture capitalists, and the capital gains tax. Journal of Public Economics, 88(5), 1011-1042. https://doi.org/10.1016 /S0047-2727(03)00046-X.

Kortum, S., \& Lerner, J. (2000). Assessing the contribution of venture capital to innovation. RAND Journal of Economics, 31(4), 674-692.

Lerner, J., \& Schoar, A. (2005). Does legal enforcement affect financial transactions? The contractual channel in private equity. Quarterly Journal of Economics, 120(1), 223-246. https://doi.org/10.1162/0033553053327443.

Lerner, J., \& Tåg, J. (2013). Institutions and venture capital. Industrial and Corporate Change, 22(1), 153-182. https://doi.org/10.1093/icc/dts050.

Li, Y., \& Zahra, S. A. (2012). Formal institutions, culture, and venture capital activity: a cross-country analysis. Journal of Business Venturing, 27(1), 95-111. https://doi.org/10.1016/j. jbusvent.2010.06.003.

Polzin, F., Toxopeus, H., \& Stam, E. (2016). The wisdom of the crowd in funding: Information heterogeneity and social networks of crowdfunders. Discussion paper no. 16-15. Utrecht: Tjalling C. Koopmans Research Institute, Utrecht University School of Economics.
Popov, A., \& Roosenboom, P. (2013). Venture capital and new business creation. Journal of Banking and Finance, 37(12), 4695-4710. https://doi.org/10.1016/j.jbankfin.2013.08.010.

Puri, M., \& Zarutskie, R. (2012). On the life cycle dynamics of venture-capital- and non-venture-capital-financed firms. Journal of Finance, 67(6), 2247-2293.

Repullo, R., \& Suarez, J. (2004). Venture capital finance: a security design approach. Review of Finance, 8(1), 75-108. https://doi.org/10.1023/B:EUFI.0000022158.96140.f8.

Robb, A. M., \& Robinson, D. T. (2014). The capital structure decisions of new firms. Review of Financial Studies, 27(1), 153-179. https://doi.org/10.1093/rfs/hhs072.

Scholes, M., Wolfson, M. A., \& Erickson, M. (2014). Taxes and business strategy: a planning approach (5th ed.). New York: Prentice-Hall.

Schumpeter, J. A. (1934 [1911]). The theory of economic development: an inquiry into profits, capital, credit, interest, and the business cycle. Cambridge, MA: Harvard University Press.

Schwienbacher, A. (2005). An empirical analysis of venture capital exits in Europe and the United States. In EFA 2002 Berlin Meetings Discussion Paper. Available at SSRN: https://doi. org/10.2139/ssrn.302001.

Shane, S. (2008). The illusions of entrepreneurship. New Haven, CT: Yale University Press.

Singer, S., Amorós, J. E., \& Moska, D. (2015). Global Entrepreneurship Monitor: 2014 global report. London: Global Entrepreneurship Research Association, London Business School.

Vismara, S. (2017). Information cascades among investors in equity crowdfunding. Entrepreneurship Theory and Practice, forthcoming.

World Bank. (2015). Doing business 2016. Washington, DC: World Bank. 